\title{
Глокализация в старообрядческой среде: модели и субъекты современной модернизации традиционалистских общностей Тувы и Буджака
}

\author{
Александр А. Пригарин
}

Одесский национальный университет им. И. И. Мечникова, Украина

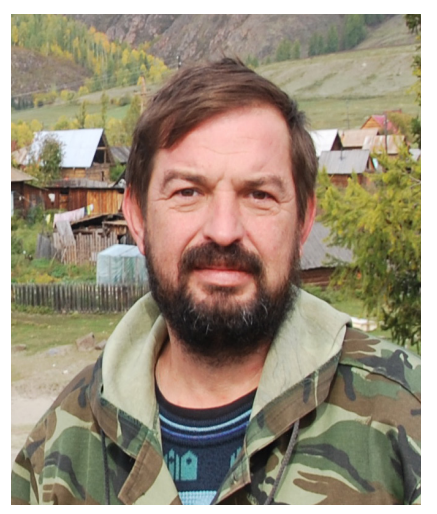

На основе оригинального полевого материала (этнографического и археографического), собранного автором в среде старообрядцев Тувы (Россия) и Буджака (Украина), рассматриваются вопросы включенности/исключенности традиционалистических сообществ в глобализационные процессы. Данная компаративная перспектива позволяет выделить общие и специфические характеристики восприятия модернизации в самобытных вариантах мировоззрения. Конфессиональные и территориальные особенности групп липован и часовенных демонстрируются в контексте стремительно развивающихся вызовов «внешнего мира», а также творческого осмысления его практик.

Подобный анализ позволяет сместить акценты с механического потребления мировых стандартов на их воссоздание и конструирование: с «импорта смыслов» $\mathrm{k}$ «адаптации идей». Показательной в этом плане оказывается христианская эсхатология, которая становится ментальной матрицей актуальной глокализации.

Ключевые слова: Тува; старообрядчество; часовенное согласие; липоване; Буджак; глокализация; модернизация; традиционализм

Пригарин А. А. Глокализация в старообрядческой среде: модели и субъекты современной модернизации традиционалистских общностей Тувы и Буджака // Новые исследования Тувы. 2021, № 3. C. 210-231. DOI: https://www. doi.org/10.25178/nit.2021.3.16

Пригарин Александр Анатольевич - доктор исторических наук, профессор кафедры археологии и этнологии Украины Одесского национального университета им. И. И. Мечникова. Адрес: 65020, Украина, г. Одесса, ул. Мечникова, 72, кв. 28. Тел.: +380505691067. Эл. адрес: prigarin.alexand@gmail.com

PRIGARIN Aleksandr Anatolievich, Doctor of History, Professor, Department of Archaeology and Ethnology of Ukraine, I. I. Mechnikov Odessa National University. Postal address: Apt. 28, 72 Mechnikov St., 65020 Odessa, Republic of Ukraine. Tel.: +380505691067. Email: prigarin.alexand@gmail.com ORCID ID: 0000-0002-6684-309X 


\title{
Glocalization among Old Believers: models and subjects in contemporary modernization of traditionalist communities in Tuva and Budjak
}

\author{
Aleksandr A. Prigarin \\ I. I. Mechnikov Odessa National University, Ukraine
}

\begin{abstract}
Making use of original archaeographical and ethnographic field material collected by the author among the Old Believers of Tuva and Budjak, the article deals with the issues of inclusion/exclusion of traditionalist communities to/from the processes of globalization. This comparative perspective allows us to focus on the general and particular aspects of how communities with specific worldviews see modernization. Confessional and territorial characteristics of such groups as the Lipovans and Chasovennye are frequently presented in the context of advancing challenges of the "outer world", and come as a creative response to this world's practices.

This mode of analysis will help accentuate how global standards are reimagined and constructed rather than simply mentally consumed, from "importing notions" to "adapting ideas". In this sense, Christian eschatology is crucially important as it turns into the mental matrix of current glocalization.
\end{abstract}

Keywords: Tuva; Old Belief; Chasovennoe accord; Lipovans; Budjak; glocalization; modernization; traditionalism

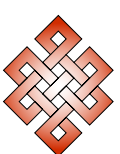

For citation:

Prigarin A. A. Glokalizatsiia v staroobriadcheskoi srede: modeli i sub»ekty sovremennoi modernizatsii traditsionalistskikh obshchnostei Tuvy i Budzhaka [Glocalization among Old Believers: models and subjects in contemporary modernization of traditionalist communities in Tuva and Budjak]. New Research of Tuva, 2021, no. 3, pp. 210-231. (In Russ.). DOI: https://www.doi.org/10.25178/nit.2021.3.16

\section{Введение}

Исследование представляет собой компаративные эссе об актуальных изменениях культурно-бытовых практик в среде староверов двух периферийных ареалов проживания - Тувы (Россия) и Буджака (Украина). Эти две территориальные группы предоставляют множество возможностей для изучения различных процессов. В данном случае обратимся к «ускользающей современности», которая представляет собой совокупность моделей жизнедеятельности, успешно консервирующих своеобразное мировоззрение и, вместе с тем, эффективно трансформирующих внешний быт жителей поселков.

Теоретической основой сравнения выступила концепция «глокализации», которая объясняет явления и процессы с позиций синхронного импорта общих стандартов путем их конвергентного освоения и формирования во всевозможных локальных средах. Согласно ей, общность быта не просто механически переносится из центров глобализации, а активно создается из местных ресурсов. С целью продемонстрировать ее продуктивность рассмотрим сюжеты акторов и моделей подобной модернизации, с упором на материальный и социальный быт.

Важными свойствами среды, несмотря на географическую удаленность условно на 6 тысяч километров, являются:

- традиционалистические варианты духовной культуры и соответствующие повседневные практики, которые ориентируются на древлеправославные образцы; 
- создание и функционирование конфессиональных сетевых сообществ задолго до всеобщей «сетевой революции»;

- наличие внутренней полифонии как важной составляющей быта, что делает этноконфессиональные группы актуальными и восприимчивыми к современному «постмодерну».

Эмпирической основой выступят полевые экспедиционные наблюдения, сделанные автором практически синхронно в Туве и Буджаке. Метод включенного наблюдения позволил фиксировать и характеризовать традиции в перманентной динамике. Экспедиционный материал собирался в течение последних десяти лет, в основных анклавах старообрядцев Придунавья и Тувы. Методической основой были: включенное наблюдение, глубинные, тематические и экспертные интервью (Spradley, 1979, 1980), биографический метод (с применением нарративного анализа) (Астафьева и др., 2001; Биографический метод ... , 1994; Denzin, 1989 и др.). Экспедиционные исследования вполне вписываются в классические принципы построения полевой работы этнологии/антропологии (Генчев, 1989; Громов, 1966; Полевая кухня ..., 2004; Russell, 1995; Chiseri-Strater, Stone, 1997; Handbook of Methods ..., 2000; Kopczyńska-Jaworska, 1971; Hammersley, Atkinson, 2000).

\section{Постановка проблемы. Объект и предмет внимания}

Исследователи социальных и культурных изменений современных постсоветских обществ больше внимания уделяли проблемам национализма, этнической мобилизации и структурализации. На этом фоне в тень уходят процессы включения в общемировые тенденции и процессы глобализации. В сегодняшней отечественной историографии данную тему следует признать аматорско-импортной. Все интеллектуальные силы брошены на анализ и пропаганду специфичности, исключительности как в историко-культурном измерении, так и в актуальной практике. Академические круги предпочитают транслировать стереотипность общественного мнения о неприятии староверами всяческих форм модернизации и унификации разных комплексов культурно-бытовых традиций.

Исходя из этого опыта, а также мысли социолога Р. Робертсона о локально-предметной форме проявлений глобализации как «глокализации» ${ }^{1}$, нам представляется продуктивным рассмотреть уровни сосуществования традиционного и модерного в двух регионах компактного проживания старообрядцев - липован Бессарабии или Буджака (Украина) и часовенных Тувы (Российская Федерация). Соотношение общих и своеобразных черт составляет основу современной бытовой практики и может выступать предметом специального исследования. Вряд ли эффективным оказывается внимание к микросоциумам с позиций только «импорта» внешнего общества потребления. В рамках такого подхода глобализация осознается исключительно как результат уничтожения «традиционных местных этнических начал и культурных архетипов» (Бондаренко, 2005: 27). На наш взгляд, современную эпоху постмодерна следует признать диалектичной - не только некие «общечеловеческие ценности» привносятся в локальную общность, но и создаются или присваиваются непосредственно в ней. Местные рынки, безусловно, зависят от транснациональных, но и сами могут выступать активными субъектами этого рынка. Равно вряд ли стоит понимать как стандартизованную модель восприятия одного и того же элемента в различных этнокультурных средах 2 . Их путь к достижениям других также является путем «изобретения» и «освоения», который может быть даже сложнее и противоречивее, чем собственно открытие и производство.

Таким образом, исследовательский вопрос можно сформулировать в следующей редакции: насколько само общество оказывается способным, подготовленным к восприятию инноваций и каким образом последние входят в органичную структуру культуры? Подобный аспект снимает с нас ответственность от аксиологических вздыханий романтиков о «добрых старых временах». Он позволяет обратиться к сюжетам реального проникновения глобальных явлений в конкретные среды. Подчеркнем, что сама среда не может играть роль пассивного потребителя, как бы ни хотелось этого любому из условных центров. В рамках историко-антропологического изучения вышеназванных общностей основные задачи находились в «прошлом»: выявление архетипов и артефактов, свидетельствующих

\footnotetext{
${ }^{1}$ Слово впервые было использовано Акито Мориата, руководителем корпорации «Sony», для успешности стратегии японского бизнеса - перенесения на местный уровень глобальных целей и перспектив. В терминологическое поле гуманитаристики его ввели Р. Рудометтоф и Р. Робертсон (подр. см.: Верменич, 2003: 15-17).

${ }^{2}$ Такое понимание вписывается в контекст современных парадигм историописаний, см.: Верменич, 2006.
} 
об устойчивости традиционалистического мировоззрения. В процессе этих полевых исследований пресловутая современность навязчиво «стучалась» в нашу «инструментальную оптику». Попробуем обобщить эти маргинальные наблюдения и представить две территориальные версии глокализации.

\section{Нюансы регионов}

Буджак (юго-западные районы Одесской области, степное Дунай-Днестровское междуречье) особый историко-этнографический регион Южной Украины. Это название (от тюркского «угол») применяется к этим территориям с XVI столетия, когда здесь проживали скотоводы-ногайцы. Их объединение - Буджацкие Ногаи, Белгородская орда - входили в состав Силистринского эялята Османской империи. В городах Измаил, Килия, Татарбунары, Аккерман проживали турки, армяне, греки и прочие.

C середины XVIII в. в Буджак начинают проникать представители многих народов - украинцы, русские, молдоване, болгары, гагаузы, греки, немцы, евреи, цыгане и т. п. В особенности этот процесс усиливается после присоединения Бессарабии к Российской империи (1812 г.), а также принудительного выселения ногайцев (1807 г.). Заинтересованное в заселении и хозяйственном освоении буджацкой степи правительство создало льготные условия для поселения и развития «задунайских» (болгары, гагаузы, греки, албанцы) и «немецких» колонистов (кроме немцев - швейцарцы, поляки). Определенная либеральность политики была также характерна и относительно государственных крестьян (украинцы, русские, молдаване). Выразительную группу составляли казацкие слои населения (УстьДунайское Буджацкое (1807) и Дунайское (Новороссийское) (1828-1868) казацкие войска).

После поражения в «Крымской» войне (1853-1856), придунайская часть отошла в состав Дунайских княжеств вассалов Османской империи. Тогда часть из жителей Буджака переселилась в Приазовье. С 1878 по 1918 гг. эти территории вновь объединились в составе Бессарабской губернии России. На протяжении 1918-1940 гг., а также 1941-1944 гг. эти районы входили в состав Румынии. В 1945-1957 гг. на украинской части Буджака была создана Измаильская область УССР, которая после реформы вошла в состав Одесской.

По данным переписи 2001 г. всего в Буджаке проживало 623662 лица или 25\% всего населения Одесской области ${ }^{1}$ Из них 40,4\% (или 251778 человек) признали себя украинцами, 20,2\% (125 988 чел.) русскими, 20,7\% (129 023 чел.) - болгарами, 12,3\% (78 888 чел.) - молдаванами и 3,9\% (24 888 чел.) гагаузами. Кроме того, здесь проживают в небольшом количестве албанцы, цыгане, греки, евреи, немцы и прочие.

Таким образом, регион характеризуется историческими и этнокультурными особенностями: относительно позднее освоение, поликультурность, социально-экономическая модерность и т. д. Важным в контексте рассматриваемой темы является то, что регион представляется традиционным практически до середины XX века. Условно раннее включение региона в капиталистические отношения сочетается со спецификой модернизации в румынское и советское время. Эти трансформации в социально-экономической и материально-технических сферах жизнедеятельности практически не затронули «традиционность» приватных практик жителей. Сформировалась уникальная сегментированность или «пакетность» повседневности, которая предоставляет широкие возможности для наблюдений над современными процессами глобализации.

На расстоянии 6 тысяч километров на восток от Буджака располагается другой предел староверия район верхнего течения Малого Енисея или «Верховье» в российской Республике Тыва (до 1921 г. Урянхайский край). Этот ареал расселения староверов относительно молодой, здесь они появились с середины XIX в. и первые старообрядческие заимки зафиксированы только в 1860-е годы (Стороженко, 2019а: 10). Уникальный геополитический статус Урянхайского края, к началу XX столетия продолжавшего находиться в составе Цинской империи Китая, в 1914 г. получившего протекторат Российской империи, а в 1921 г. ставший Тувинской Народной Республикой, определялся во многом внешними факторами. Все эти стремительные социально-политические трансформации происходили на фоне интенсивного хозяйственного освоения региона русским населением, формированием оседлой поселенческой структуры, активного межкультурного взаимодействия. В результате в первые десятилетия XX столетия в Центральной Азии сложился фронтирный поликонфессиональный регион.

\footnotetext{
${ }^{1}$ Подсчитано по: Численность и состав населения Одесской области по итогам Всеукраинской переписи населения 2001 года [Электронный ресурс] // Всеукраїнська перепись населення 2001 p. URL: http://2001. ukrcensus.gov.ua/rus/results/general/nationality/odesa/ (дата обращения: 10.05.2021).
} 
Постепенное увеличение численности русских, как православных, так и староверов, молокан, баптистов, наблюдавшееся до начала XX века, в первой четверти столетия кратно увеличилось - c 4 тысяч до 25 тысяч. При этом доля последователей старой веры долго сохранялась примерно на уровне одной трети от общего количества русских (Стороженко, 2019b: 168; Стороженко, Татаринцева, 2019: 89). Общее количество русскоязычного населения увеличилось с 4385 душ обоего пола в 1913 г. до 11958 душ обоего пола в 1919 г., т. е. увеличение произошло в 2,73 раза (Стороженко, 2018: 47). Изначально староверы расселились почти по всей территории Тувы, предпочитая земли, не занятые тувинцами и стремясь образовывать монопоселения, «подальше от оживленных дорог, православных священников и государственных структур» (Стороженко, Татаринцева, 2019: 88). С середины ХХ века, когда в 1944 г. ТНР вошла в состав СССР, староверы начали сосредотачиваться в локальной зоне - верховье Малого Енисея (территория Каа-Хемского кожууна Тувы) (Стороженко, 2019а), по образному выражению М. П. Татаринцевой - месту притяжения, где предпочитали селиться последователи часовенного согласия и до начала XXI в. были их духовные центры - скиты (Татаринцева, 2018: 179).

Таким образом, эти два ярких и самобытных историко-этнографических региона Евразии ограничивают «Великую степь». Наблюдается некоторая схожесть в историческом развитии, несмотря на значительную дистанцию (в рамках наших задач подчеркнем относительно поздние модернизации, совпавшие с советизацией регионов со второй половины 1940-х гг.). При этом наблюдается экологическая специфика: если тувинское «Верховье» представляет собой практически исток Енисея с труднопроходимой тайгой, то Буджак - устье Дуная, находящееся в степи. Староверы в обеих случаях выбирали труднодоступные места для расселения, избегая прямых контактов с внешней средой. Как общность исторических судеб, так и специфика расселения представляют широкие эвристические возможности во время компаративного анализа.

\section{Нюансы групn}

В числе прочих этнокультурных групп Буджака и Тувы выделяются самобытностью русские старообрядцы: «липоване» (Prygarin, 2004; Пригарин, 2004; Смилянская, Денисов, 2007) или «часовенные» (Покровский, Зольникова, 2002; Татаринцева, 2006), соответственно.

Феномен старообрядческой культуры в общеславянском контексте не сводится к простому многообразию историко-этнографических и этноконфессиональных вариантов русскости, но и определяется самобытными типами мировоззрения и их воплощением в оригинальные формы практики, которые сохранили в современности немало архаических черт. Благодаря этому старообрядческая среда сохраняла выразительные комплексы, которые за ее пределами уже давно стали редчайшими анахронизмами (крюковое пение, византийские каноны иконописи, старопечатные книги и рукописные традиции и т. п.). «Особую важность... имеет необходимость и умение члена старообрядческой общины, - подметила И. В. Поздеева, - жить сразу в двух эпохах, владеть двумя «культурными кодами»: древней духовной и современной материальной жизни» (Поздеева, 2006: 263).

В контексте такого понимания обе общности могут быть охарактеризованы как субэтнические варианты русскости в инокультурном окружении. Среди выразительных их свойств стоит выделить: трансграничность (расположение на пограничнье и ориентированность на международные масштабы жизнедеятельности); этноконфессиональность (группа возникает и функционирует в результате одновременного действия этнических и религиозных факторов); замкнутость и традиционализм (сознательная мировоззренческая ориентация на сакрализацию «старого», «традиционного»); субэтничность (наличие всех признаков такого рода групп, включая уникальную структуру идентичности); диаспорность (параллельное осознание своей принадлежности к разным политическим пространствам с сохранением романтической связи с исторической родиной). Специфичность групп может быть описана в категориях последовательной сохранности: липоване в силу относительно ранней включенности в модернизацию оказываются более размытой общностью, а вот часовенные - в своей сознательной практике, избегая влияния внешней среды, наоборот, группа с четкими границами, ориентированная на мобильность как модель «спасения».

Обе группы достаточно многочисленны, насчитывая более 100 тысяч человек, они достаточно широко расселены по миру. Кроме исторического ареала липован в Украине, Молдове, Румынии и Болгарии, их дочерние «диаспоры» расположены в Российской Федерации, Италии, США и т. д. Часовенных Тувы следует признать лишь одним из очагов проживания, наряду со всей Сибирью, Уралом, Китаем, Южной и Северной Америкой. 
Вплоть до настоящего времени внутригрупповая интеграция обусловлена синхронным действием этнокультурных и конфессиональных факторов. Осознание себя частью русского народа, невзирая на почти трехсотлетний период собственной истории, сочетается с ревнивым сохранением своего старообрядчества. Находясь в иноэтнической среде, культуры и липован, и часовенных испытали значительное воздействие опыта своих соседей, сохранив ядро своей этничности. В ряде случаев наблюдается взаимодополняемость и взаимозаменяемость этнических и конфессиональных стереотипов и символов. Например, «церковная» одежда представляет собой нечто иное, чем традиционный костюм. Внутригрупповой билингвизм (старославянский язык как ритуальный и русский диалектный как бытовой) сочетается с внешней диглоссией - активное общение с соседями на их языках.

Такая «многоликость» сочетается с устойчивостью духовного стержня на групповом и индивидуальном уровне. Специфика современного этапа несколько дублирует предыдущий опыт очередное испытание. Но если раньше модели вступали в механическое противоречие - выжить означало не принять окружающий мир, нередко репрессивно преследовавший людей старой веры, то теперь - этот мир оказался включенным в старообрядческую среду.

«Для большинства верующих неизбежно увеличение фрагментации, жизнь в нескольких реальностях с принципиально отличающимися правилами взаимоотношений, - пишет Д. Е. Расков о “постмодерне как оболочке” в старообрядческой среде. - Неизбежно соприкосновение и использование новейших технических изобретений и достижений современного информационного общества. К таким “новинам", как картофель, табак, чай, электричество, телевизор теперь добавились компьютер, цифровой штрих-код на всей товарной продукции, кредитные карточки и многие другие вещи, которые требуют осмысления» (Расков, 2007: 56).

Сравнение групп показывает специфику: последовательное неприятие новшеств со стороны часовенных и, наоборот, активное использование инновационных технологий в среде липован (например, осуждение на соборе смартфонов у первых и пользование социальными сетями для религиозных нужд липованами Украины и Румынии).

Оказывается, что традиционные структуры как никогда востребованы в обстоятельствах глобализации. Опыт групп убедительно свидетельствует о мистически-метафизическом ожидании Спасения духа и параллельной успешной активной практике адаптации и приспособления к миру внешнему. Этот вроде как логический парадокс убедительно раскрывается в отношении роли старообрядцев в экономическом и техническом прогрессе российского общества (Керов, 2016).

В силу этого современная практика староверческих групп предоставляет яркие и оригинальные эвристические возможности для наблюдений над современной глобализацией.

\section{Методы и концептуальная проекция}

Для обобщений и анализа удачной оказалась операционная схема «пакетности»- сосуществование различных укладов жизни и практических стратегий в эпоху глобализации. Удивительным образом наблюдения исследователей старообрядчества стали созвучны идеям П. Бергера (Бергер, 2004: 19). Для характеристики процессов глобализации, ученый использует термин «пакет / пакеты» (package, packages), который предлагает понимать как модели поведения и сознания людей, традиционно проявляющиеся в определенных сферах социальности. В условиях глобализации некоторые «пакеты» легко комбинируются между собой без остановки модернизации, другие же, напротив, вступают в противоречие и вызывают конфликт смыслов.

Подобное понимание параллельного сосуществования и одновременного со-действия «языков или кодов культуры» еще раньше сложилось в исследованиях ревнителей «древлего благочестия». Так, глубокие наблюдения Е. Е. Анастасовой о цикличности моделей (читай - пакетов) старообрядческой культуры: этноконфессиональная общность (детство и старость) - маргинальная общность (зрелость). Это важно для понимания механизмов воспроизводства социума, в основе которого находится религиозная традиция. Центральными акторами процесса являются когорты в процессе социализации и готовящие к переходу в мир иной. Кроме этого, к конфессиональному центру относятся лица, избравшие праведную жизнь как стратегию - священство, монахи, чтецы, дьяки и т. д. Остальные члены общины менее связаны с традицией и обеспечивают ее физическое и материальное выживание. Такая модель дает понимание и настоящего и прошлого группового опыта. Аналогично, синхронный анализ ритуальной чистоты и ее концептуализации в среде часовенных, позволил Д. С. Рыговскому выявить «пакетность» на уровне социальных структур и практик (Рыговский, 2018b). 
Жесткость мировоззренческих границ-пакетов в отношении «двух дорог» жизненных стратегий продемонстрировали как бинарный код прочтения на визуальном материале Е. В. Быкова и А. В. Костров (Быкова, Костров, 2018аb).

Относительная общность жизнедеятельности и процессов позволяет моделировать материал в условных категориях «старообрядческих общин Буджака и Тувы», указывая, где это требуется специфику. Такая сознательная анонимность продиктована и этическими аспектами исследования явления из экономических, социальных и религиозных сфер современной жизнедеятельности требуют от нас именно такого корректного подхода.

\section{Традиция и инновация: восприятие нововведений и их знаковые свойства}

Современный опыт переживания глобализации для старообрядцев вписывается в предыдущий контекст: в мистических концептах глобальность в виде «Конца Света» наступала неоднократно для мировоззрения староверов. Признаки глобальности воспринимаются и расцениваются в рамках устойчивой эсхатологической проекции.

Представления о конечности мира - важная составляющая христианского мировоззрения, во многом предопределившая пути развития старообрядчества. Мистическое ожидание Второго Пришествия в старообрядческой среде не являлось сугубо созерцательным процессом. Им было порождено отрицание социальной активности в сочетании с неприятием новшеств. Но им же и обусловлено было чувство мобилизации во имя противостояния Антихристу. «...Конец света нужно встречать созидаючи, - считали староверы XX века, - Господь должен застать нас не в унынии, а в созидании» (Трушкова, 2002: 448). Такая трансформация определила своеобразие социальной практики, например, в вопросах формирования капитализма и роли в нем старообрядческой составляющей (Керов, 2016). Еще одним важным качеством эсхатологии является ценностный фильтр преобразования современных событий и выстраивания прошлого группы, как признаков приближения Страшного Суда.

Напряженность и активность эсхатологических ожиданий наблюдаются в периоды рубежных дат (смена веков, тысячелетий - по светским или религиозным календарным системам), социальных потрясений (революций, войн), необычных природных явлений (засуха, неурожай, кометы, наводнение, затмение и т. д.). Иными словами «резкие исторические разломы воспринимаются как конец старого, привычного и начало нового, еще не известного мира» (Сморгунова, 1996: 22).

Несмотря на обилие в опыте липован такого рода событий, отношение к ним отличалось относительной сдержанностью. Ожидание Страшного Суда не породило сколько-нибудь самобытной стройной регионально-культурной концепции (по крайней мере, пока не выявлено) ${ }^{1}$. В канун 2000 г. наши наблюдения показали, что мистический настрой старообрядческих общин вряд ли был выше, чем среди окружения. Идея рубежности времен скорее транслировалась СМИ, нежели породила внутренние рефлексии.

Приведем лишь один пример. В одном из старообрядческих хуторов дьяк Егор долго и охотно общался с нами на тему Апокалипсиса, но, указывая на его приближение, брал явные примеры из газет. Состоявшееся полное солнечное затмение должно было породить усиление религиозного предчувствия. Односельчане собрались в храме и устроили совместное моление. Практически сразу этот факт обрел полумифологическую форму среди соседних болгар, молдаван, украинцев - они рассказывали, что липоване все обнажились и ожидали затмение в воде, читая спасительные молитвы. В данном случае неизвестность ритуальной практики староверов породила суеверные домыслы.

По всем поселениям липован носителями таких эсхатологических настроений выступали начетчики или люди близкие к конфессиональному центру. Именно с их слов транслировались описания Последнего дня и его признаков (со ссылкой на книгу, в которой это все было написано). В этих меморатах обращает внимание, что атрибуты Второго Пришествия выходят на первый план, затмевая содержание Страшного Суда. Современная техническая модернизация жизни привела к

\footnotetext{
${ }^{1}$ Хотя именно в близкой к липованам группе днестровских староверов зафиксирован позднейший пример последовательных действий - десятки семей замуровали себя заживо, протестуя против переписи 1897 г., указывающей на приход антихриста (Печальный фанатизм среди раскола в виду переписи // Прибавления к Херсонским епархиальным ведомостям. 1897, № 10. С. 290-291). Также стоит отметить, что в библиотеках старообрядцев региона немало выявлено книг и рукописей эсхатологического характера. Но абсолютное большинство из них - привозные, а не оригинальные.
} 
ответной реакции -установленным фактом является семиотизации новшеств как признаков Конца Света - железные дороги, телефоны, переписи населения, паспорта и т. д. (Сморгунова, 1996: 22). В свое время - чай, табак, картофель и другие инновации (Романов, 1901).

Социальные перемены конца 1940-1950-х гг., а также урбанизация культуры в последующем, привела к вертикально-поколенной дифференциации. «Старики» продолжали жить по-старому, отказываясь от инноваций:

«Матушка моя сказала: “Вы как хотите, а мне оставьте кухоньку”. И электричество туда провести отказалась, и радиво. Когда пришла Советская власть, а у меня матка уже была старенькая, то проводили радивопроводку. Я хотел провести, а матка сказала: “Если приведешь Чорта у хату, то я со двора уйду”. Радиво считали от нечистого. Я считаю, што всё от Бога. А вот матка, наоборот. Потом, когда матка в кухне жила, я радио провел. Один раз службу из Ватикана передавали. Я матку позвал - она послушала и говорит: “О, сынок, там тоже Бог сидит”. И с тех пор стала иногда слушать. “Москва говорит, Аксинья, Москва”. “То не Москва говорит, то чорт говорит”»1.

Или: «Фотографироваться батя не давался: “Чорту буду показывать своё лицо?!” Такой был религия»².

Отдельные новшества были приняты с особой «теологической» поправкой. Например, в Вилково лодки на моторах стали применять быстро. И здесь бытует бывальщина, что один дед говорил: «Плохо, когда черт на тебе ездит, а вот если ты - на нем, то это даже бравенько (хорошо. - A. П.)».

Как нам удалось зафиксировать, именно в поколении 1900-1910 г.р. бытовали эсхатологические поверья, которые затем активно транслировались в последующие когорты, однако уже с меньшей интенсивностью. Характерно также, что в каждом из сел называлось по памяти лишь два-три признака наступления времен Антихриста. Показателен набор этих признаков - он имел четкое локальное выражение. Так, в одном из сел устойчиво указывали, что «вино станет стоить дешевле вина» (примером такой ситуации приводили Кока-колу или аналогичные напитки); в другом - «женщины оденут мужскую одежду, перестанут мужчины от женщин отличаться»; в третьем - «всех пронумеруют» и т. д. «В Писании сказано: будут девицы - бесстыжие лица. И, правда - сейчас женщины как мужчины» ${ }^{3},-$ говорила нам одна из липованок.

Разрыв в советский период традиционных механизмов передачи религиозных знаний привел к выпадению из подобных эсхатологических настроений целого поколения. На момент наших исследований «распознавателями» знаков Антихриста стало «позднее советское» население. Это успешные люди, вполне включенные во всевозможные коммуникационные и социально-экономические связи к предпенсионному возрасту, «возродили» старую мировоззренческую парадигму. Остаточные детские знания в сочетании с новыми рефлексиями нередко порождают у них образы «глобальной катастрофы». Она достаточно синкретична и выделить в ней уровни старообрядческих и общечеловеческих представлений не представляется возможным (Анастасова, 2006). «Бесовские знаки» ими видятся и в Горбачеве ${ }^{4}$, и в самом переходе к новым государствам и режимам, и штрих-коде (ЕAN), и в росте преступности, и в проявлениях глобализации. Это не мешает им активно осваивать технологические новшества - мобильные телефоны, компьютерную технику, банковские карточки и т. д.

В одной из рукописей - варианте сочинения «О появлении зверя сатаны» К. К. Горбунова - все эти признаки глобализации рассматриваются как проявление воли Люцифера (Соболева, 1997: 118-130). Любопытно, что в одном из списков проводниками его воли определяются «иллюминаты - со-

\footnotetext{
${ }^{1}$ Записано со слов Наумова Клима Зиновеевича, 1924 г.р., русский, с. Мирное Килийского района Одесской области, Украина.

2 Записано со слов Димитрова Ивана Семеновича, 1913, г.р., русский, с. Муравлевка, Измаильского района Одесской области, Украина.

3 Записано со слов Колесниковой Агриппины, 1927 г.р., русская, с. Старая Некрасовка Измаильского уезда Одесской области, Украина.

${ }^{4}$ Удивительным образом сливаются образы негативного восприятия советской власти как воцарения Антихриста с ее концом. Ленин или Троцкий воспринимались как собственно Антихрист (см., например: Еп. Иннокентий (Усов) «Апокалипсические чудовища». Кишинев, 1935).

${ }^{5}$ Один из наставников Часовенного согласия на Урале написал эту рукопись в $1980-\mathrm{x}$ гг. С тех пор не раз его работа творчески переосмысленной фиксировалась в разных группах староверов (см., например: Соболева, 1997: 118-130). Нам доводилось с ней «встречаться» среди липован Румынии и Украины, а также в Черниговской области. Относительная популярность этого и похожих текстов устойчиво фиксируется среди староверов Енисея.
} 
временные “блага”, к которому стремится все человечество иметь: машину, роскошный дом, квартиру, одежду модную, ковры и т. д.» (ПМА, 2008, с. Старая Некрасовка, Измаильский район Одесской области Украины; здесь и далее выделения мои. - А. П.). А как можно избежать этого? Защитным механизмом традиционного праведного пути являлись ранее -изоляция и миграции. Сегодня это уже не актуально:

«Вы сами - решение всех Ваших проблем... Если Вы проверите, кого выбираете и что Вы поддерживаете каждый день, весь мир будет для Вас выглядеть по-иному, а Иллюминаты не будут иметь над Вами никакой власти. Под словами Вами я понимаю всех жителей этой планеты» (там же: выделено в цитате нами. - A. П.).

Очевидна и актуализация современного рассказчикам опыта. Конечно, сохраняется память о «железных конях / птицах», «паутине по всему миру» (этот образ среди поколения людей знакомых с компьютерами и Интернетом переживает реституцию) и другие широко известные образы (Быкова, Пригарин, 2019: 85), но они отходят на второй план и «припоминаются», не имея серьезной эмоциональной окраски.

Ретроспективность эсхатологического опыта демонстрируется еще одним моментом. Ухудшение социально-экономического положения и расшатывание моральных устоев в обществе привело к трагическим массовым кражам икон из домов и храмов. «Деды говорили, как будут Богов воровать, то времена настанут смутные», - расценивают современные реалии как сбывшиеся предсказания.

Среди часовенных Тувы эсхатологические настроения намного последовательны. В этой среде не прерывалась традиция восприятия всех вызовов внешней среды как угроз или признаков Конца Света. Если эти сюжеты среди липован можно выявить исключительно у представителей конфессионального центра, то в среде часовенных они присутствуют практически повсеместно. Цитированный выше К. Горбунов, как раз являлся одним из мыслителей уральской ветви часовенных. Кроме того, можно вспомнить такого автора как А. Г. Мурычев (Зольникова, 2018; Быкова, Пригарин, Стороженко, 2018), который посветил немало своих интеллектуальных усилий комментариям Апокалипсиса, составив даже специальную «периодическую таблицу» признаков пришествия Антихриста. Просто перечислим название большинства его сочинений: «Краткое выяснение о временах из апокалипсических знамений» (1963); «О временах» (1969-1970); «Толкование на Апокалипсис» (1970); «Пред атомные предвестия» (1984); «О конце света» (1994); «О начертании» (1990-е гг., до 1997 г.); «Периодическая таблица Апокалипсиса» (1999).

Для понимания группы важно не только наличие авторских текстов, сколько присутствие подобных идей в повседневных социальных и религиозных практиках. Д. С. Рыговский четко прослеживает связь между эсхатологическими настроениями «с вопросами соблюдения индивидуальной ритуальной чистоты. К последним, помимо известного разделения посуды для старообрядцев и мирских, относится отказ от пенсии и других выплат со стороны государства, а также от некоторых документов, вроде ИНН, СНИЛС и т. п. К этой же категории должны быть отнесены освящение продуктов и употребление крещенской (богоявленской) и спасовой воды (Рыговский, 2019а: 1). Перейдя на уровень «малой эсхатологии» часовенные последовательно отгораживают себя от «мира Антихриста» и «признаков его прихода».

Все эти глобальные признаки Конца Света и составляют суть старообрядческого восприятия современных процессов. Инновации стимулировали размышления и толкования, которые обращаются к уже имеющемуся в прошлом религиозному опыту. Сакральный переход совершило мировоззрения староверов - если изначально Апокалипсис осознавался как процесс глобальный, то теперь его значение перешло на индивидуальный уровень - от «Большой» к «Малой Эсхатологии». Воцарение Антихриста в мире вывело на передний план вопросы собственного спасения, очищение души личности и общины. Такие процессы крайне созвучны понятию «глокализации» - общая бесовская стихия приводит к локальным протестам и сопротивлению.

При всем подобном восприятии новшеств они активно используются в старообрядческих общинах. Этот некий парадокс можно раскрыть через классификацию моделей включенности сознательно изолированных религиозных сообществ. Согласно нашим наблюдениям, таких моделей современной трансформации может быть предложено несколько. 


\section{Общегрупповые практики (урбанизационный фон на селе)}

Изменения внешнего быта и производства на современном этапе является результатом повышения комфортности и продуктивности. Вот почему староверы оказываются втянутыми в общие процессы проникновения технических и материальных инноваций. Все они производятся «где-то» в центре и транслируются на сельскую периферию. Их применение расценивается как эффективное продолжение прошлых техник (см. вышеприведенный пример восприятия лодочных моторов в Вилково). При всей ритуальной нечистоте покупных вещей технологии проникают даже в мир часовенных. Так, например, снегоходы или автотранспортные средства имеются в семьях, которые строго придерживаются всех предписаний Соборов. Показателен пример школьных тетрадок, в которых вырезается или закрашивается штрих-код. Большинство староверов воспринимает его как «знак Антихриста», «завиняя его». В большинстве тувинских общин не получили своего развития идеи А. Г. Мурычева, который полемизировал с баптистами относительно этого эсхатологического сюжета, считая это «мракобесием».

Существенным фактором актуальной модернизации выступил предыдущий «советский» опыт. Отказ и избегание товаров от «греховной власти», стимулировал импорт из Китая, с одной стороны, а, с другой - консервацию этнографического натурального хозяйства и уклада. Рефлексируя об этом, М. П. Татаринцева отмечает:

«Наставники запрещали использовать ту часть бытовой техники, которая могла разрушить идеологию староверия, посеять сомнения в душах верующих, пошатнуть веру» (Татаринцева, Стороженко, 2015: 79);

«Строго придерживаясь дониконовских старинных церковных правил, обрядов, обычаев, старообрядцы связывали эту церковную обрядность с элементами традиционной русской бытовой культуры, и материальные формы культуры рассматривали уже как некую божественную сущность, часть старой веры, непременную принадлежность старообрядчества» (там же: 72).

При этом инновационные комплексы не могли не входить в практики: орудия охоты, рыбной ловли, обработки земли, транспорт, электричество...

Таким парадоксальным образом начинается сочетание представлений о греховности техники с ее повсеместным использованием в старообрядческих поселениях. Такое положение дел оправдывается тем, что техника используется исключительно в трудовых целях, поскольку без нее невозможно жизнеобеспечение сообщества, особенно в таежных условиях. Г. А. Любимова отмечала эту тенденцию, ссылаясь на концепцию Валерия Керова о «благословенной вине», т. е. о существовавшем в старообрядчестве религиозно-этическом обосновании пользования техникой, если это было необходимо для развития хозяйства или предпринимательской деятельности; данное обстоятельство в значительной степени способствовало модернизации сельского хозяйства староверов (Любимова, 2017: 126, 129). Так потребности жизнеобеспечения приводят к сдвигам в системе запретов старообрядцев, заставляя их переосмыслять собственные взгляды на область современной техники.

Полемизируя с подобной трактовкой, Д. С. Рыговский отмечает, что

«Вина, а точнее “завинение” различных предметов, существует как религиозная практика часовенных: любые потенциально опасные объекты, будь то банковские карты, товары со штрихкодами, документы (особенно электронные или содержащие биометрические данные) и многое другое требуется “завинять”, т. е. признавать, что их использование не полезно для души и раскаиваться в том, что приходится иметь с ними дело. При этом идеалом считается полный отказ от подобного рода вещей. Во-вторых, речь идет не только об устройствах, облегчающих домашний труд. Подобные отношения часовенные имеют, например, с мобильными телефонами. Как объяснить их распространение, если телефоны ассоциируются со сферой развлечения, а не собственно труда? В-третьих, необходимо отметить, что некоторые запреты в этой системе более актуализированы, чем другие. Об одних вещах говорят и волнуются постоянно, они обсуждаются и являются частью актуальной эсхатологии, в то время как другие запреты, даже если они были сформулированы и отражены в решениях соборов, не имеют подобной остроты и как будто забываются. Здесь уместно вспомнить о борьбе наставников часовенных с радио и рациями, которую они вели всю вторую половину XX в. и в самом начале XXI в. Полемика против использования этих устройств угасает после того, как у часовенных появляется новая угроза - мобильный телефон. При этом радио и рации не исчезают из старообрядческого быта: к примеру, рации до сих остаются необходимым средством связи в таежных поселках. Однако никто уже не воспринимает их в эсхатологическом ключе. Иными словами, хозяйственная необходимость до конца не оправдывает применение техники, а взаимоотношения старообрядцев и технических устройств не описываются до конца в предложенных на данный момент терминах» (Рыговский, 2019с: 26). 
Для липован, наоборот, практически во всех отраслях хозяйства (рыболовство, земледелие, торговля) проявляется инновационный потенциал. Нередко при этом именно внешность происхождения таких новшеств не требует специальных рефлексий.

Приведем несколько ярких примеров такого рода глобализационных моделей. Одно из поселений в силу торговой конъюнктуры включилось в выращивание раннего картофеля. Несмотря на дискуссии в других регионах старообрядцев о картофеле как «бесовском плоде», эта община достаточно быстро стала ведущим производителем этой культуры. Аналогично обстоит дело с выращиванием табака (!), который был и остается основой жизнедеятельности еще одного старообрядческого села. Предприниматели из старообрядческой среды придунайского городка еще в советское время стали пионерами изготовления и продажи капроновых чулок и колгот.

Явления этого порядка мы склоны расценивать как неизбежное проявление импорта городской культуры на традиционную среду. Благодаря этому создается перманентный «урбанизационный фон» - стремление в быту и в экономических стратегиях равняться на достижения цивилизации. При этом для старообрядцев эти инновации не должны вступать в видимое противоречие с традиционным. Яркое проявление этого - сохранение курных парных бань на дворе, несмотря на наличие ванн, душей и джакузи в самом доме. Обратный пример - многочисленные приходы проповедников всевозможных сект. В отличие от соседнего населения староверы не приняли этих агентов глобализации - ни в одном из поселений им не удалось обосноваться (исключение составляет лишь Мирное, где молитвенный дом евангелистов располагается на «хохляцкой» (никонианской) части села).

Иногда «город» или «цивилизация» сама настойчивостучится вприоткрытыедверистарообрядческих общин. Например, Вилково и Приморское становятся международными туристическими центрами, в т. ч. благодаря экзотичному быту и своеобразию жителей. Однако туристы, приносящие доход этим общинам сопоставимый с традиционным, требуют новых стандартов.

\section{Агентурные связи}

Кроме общих процессов урбанизации, нередко их точечное или капиллярное проникание. Явления проникания внешней среды в имманентные связи самой общины посредством фрагментарного воздействия предлагается определять как «агентурные связи».

Будучи активными в хозяйственно-экономической жизни, липоване еще с XIX в. освоили «отходничество» на промыслы. Со временем география их заработков только расширилась. Среди таких традиционных занятий, которые оказались востребованы на современном этапе, являются: строительство (каменщики, плотники), извоз, мелочная торговля, земляные работы и т. д. Рыболовство частично трансформировалось в морское дело (достаточно велика доля моряков выходцев из исторических анклавов старообрядцев). По функции близко к этому находится и служба в армии.

Такой уклад жизни предполагал проживание во внешнем мире, активную деятельность в «иной» среде. Он сочетал как минимум два «кода» разновекторной направленности: для «своих» (внутренний) и «чужих» (внешний). Например, по обычаю мужчина не должен был брить бороду, что полностью было исключено на службе в армии.

В других случаях комбинирование жизненных пакетов происходит в более краткий период времени. Например, в течение суток - радиальная миграция в город на работу. Прихожанин преодолевает социокультурную дистанцию не только в территориальном измерении, но и испытывает перманентный «переход» - от «своего» мира во внешний и обратно.

Явный результат глобализации - виртуальное путешествие. Находясь в пределах своей конфессионально-территориальной общины, старообрядец связывается посредством Интернета со множеством носителей «иных» мировоззрений и практик. Со-действие укладов и стандартов в этом случае менее очевидно, но ощутимо. Оно меньше касается бытовых атрибутов, а направлено на ментальные уровни. Масштабы такой агентурности подчеркиваются стремительным ростом количества и качества ВЭБ-ресурсов - от форумов до Life-Journals, от информационных сайтов до пользователей простых почтовых служб.

В меньше мере, эти «агентурные связи» проявляются среди часовенных Сибири. Хотя и они, будучи сознательными сторонниками отхода на промыслы в тайну, не сумели избежать сезонных экономических миграций. Целый ряд обстоятельств лишают традиционные промыслы (охоту и рыболовство, собирательство) товарности, а, следовательно - смысла. Вместо этих натуральных 
стратегий жизни все чаще доводится староверам покидать пределы своих общин не в сторону тайги, а в городские центры или для строительства и торговли. Подобная «агентурность» и привнесение новых стандартов все больше ощущается в часовенной среде.

Приведем один яркий пример. В одном из городов «енисейского меридиана» довелось общаться с таксистом, который признался, что «кержак» по происхождению. Одновременно он гордился и своей принадлежностью, и своей включенностью в этот эффективный образ жизни. Оказалось, что он стремится регулярно посещать свою родную общину, поддерживать родственные и конфессиональные связи. При посещении родственников нередко покупает в подарок современную технику. Будучи внешним по отношению к «собору», он надеется в него вернуться на старости лет, а инновационный опыт воспринимает как необходимость и комфортность.

\section{Обмирщение - внутренний и внешние варианты выхода}

Столкновение традиционных и современных элементов в старообрядческой среде может приводить к выходу из общины. Говоря языком самих носителей данной культуры - к «обмирщению». Глобализация породила более мягкие модели этого процесса. Если в условиях домодерного сообщества исключение из общин означало фактическую смерть личности - ее изгоняли из всей совокупности социальных коммуникаций и вынуждали покинуть общинное пространство, то в современных практиках Миры продолжают сосуществовать.

Лишь немногие верующие на протяжении всей жизни исполняют все предписания этикетноритуальной стороны своей религиозной приверженности. Большинство же вынуждены в социально активном возрасте включаться во внешний мир, испытывать воздействие все той же глобализации и унификации. Уже такое поведение может быть расценено как «обмирщение». Каковы же варианты этой модели? Их оказывается всего два - исход и исключенность.

Первый предполагает окончательную победу глобального мира. Человек оказывается полностью втянутым во внешнюю среду. Как правило, он переезжает на новое место жительство. Иногда причина меняет свое место со следствием - уход в город способствует разрыву старых коммуникационных связей со своей общиной. Элементы традиционного уклада и религиозной практики присутствуют в его жизни лишь формально, на уровне отдельных атрибутов - нательный крестик, отцовская икона, дедовская книга и т. д. Традиционная структура представлений и соответствующего поведения оказывается разрушенной.

Второй вариант - реликтовое проживание в своей территориальной общине, но не вхождение в ее религиозные границы. В результате советизации и глобализации целый ряд личностей попали в маргинальное положение в своей родной культуре. Ярко это видно по людям с девиальным поведением - «табакокурам», пьяницам, наркоманам и т. д. Нарушив основные христианские запреты, они самостоятельно себя выставили из общины своих родителей. Мало того, что они лишены ритуалов и таинств своих предков, сами предки оказываются вне «закона» - родителей, у которых дети живут невенчанными (не говоря уже о нарушителях запретов), священник может не отпеть в храме, не пустить на исповедь, не пустить под крест и т. д. С одной стороны, это инструмент воспитания, а с другой - тяжкое наказание.

«Глобализаторы» такой модели выступают не только символом «новых времен», но и со временем могут стать их прямыми трансляторами. На протяжении жизни все они пытаются сохранить свою эмоционально-романтическую приверженность своей малой Родине. Чаще всего, это выражается в посещении своего поселения и церкви на Пасху и/или престольный праздник. Бывая неоднократно на таких службах, нам доводилось видеть жителей далеких от данного села жителей - Одессы, Москвы, Кишинева и т. д. Кроме того, согласно верно подмеченной модели Е. Е. Анастасовой (Анастасова, 1998: 25) , вступая в пожилой возраст, многие возвращаются к истокам. Начинают жить «по закону», соблюдают предписания старообрядческой веры, ходить в храм и т. д. Нередко из таких «возвращенцев» формируется конфессиональный центр общины. Например, бывший участковый стал пономарем, бывший учитель - священником, бывшая комсорг колхоза - крылошанкой (поющая службы на «крылосе») и т. д.

Такими основными путями достижения глобализации активно включаются в старообрядческую среду. Модели этого, несмотря на всю их разницу, вполне отражают единую смысловую составляющую - привнося инновации, они фильтруют их через мировоззренческую парадигму. Вот, наверное, почему староверы оказались практически спокойными к материально-технологическим аспектам 
«прогресса», но крайне требовательными к вопросам веры. Активные поколения воспринимали новшества для эффективного выживания как себя, так и своей веры. Старшее поколение заботилось о ее сохранении и «проверяло» соответствия христианских представлений. А младшие - одновременно осваивали мудрость, духовность и душевность дедов, а также технический опыт отцов.

Еще более заметны эти же тенденции в среде часовенных Сибири. Здесь варианты «обмирщения» напрямую связаны с (не)участием в различных аспектах жизнедеятельности общин (подчеркнем, что не исключительно религиозных). Нередко доводилось слышать от вполне «соборных» охотников рассказы об искусах внешнего мира. О таких говорят, что они в поселках в целом соблюдают запреты на проявления инновационных техник и технологий, а вот, «на заимках» вынуждены отходить от части из них. Заметным маркером этого выступает система «чашки»: придерживание посуды осуществляется не столько изначально, но и в зависимости от контекстуальных оказий. Если человек оказался втянутым во внешний мир и «завинился», то он на время лишался возможности общаться в общей трапезе (Рыговский, 2019b, 2018a).

\section{Акторы глокализации}

Модели проникновения глобализационных влияний в старообрядческой среде реализуются через деятельность ведущих субъектов. Эти носители, как правило, традиционного мировоззрения, вступая в многочисленные коммуникации с внешним миром, привносят инновации из него. Типы таких «проводников» или «акторов» разнообразны. Приведем лишь типичные из них.

Священник / Наставник. Как это не парадоксально, но именно священство играет важную роль в глокализационных процессах. Духовные наставники общин (возможно расширить эту группу до всего конфессионального центра) являются важнейшими «фильтрами» инновационного опыта. Заботясь о сохранении духовных начал, они вместе с тем способствуют аксиологической оценке новшеств, которые порождаются контактами с внешним миром. Они же выполняют основные репрезентативные функции группы перед обществом в целом, отображая недифференцированность традиционных ветвей «власти» (духовной и светской).

Поддержка ими христианского космического мировоззрения порождает общий фон глобализации, в православном ее варианте. В силу этого формируется такая черта ментальности как глобальность в оценках и суждениях. На нее легко могут «нанизываться» внешние атрибуты глобального мира, получать свои оценки и приниматься/отвергаться для повседневной практики.

Есть еще один важный фактор глобализации, который реализуется посредством священников среди липован Украины. Если ранее их выбирали из своей общины, то советский период подорвал этот обычай. В силу ряда понятных причин в 1990-х гг. общины оказались без своего священства. Тогда иереев начали выбирать из представителей других регионов - Москва, Кишинев и т. д. Из 7 существующих священников, лишь двое представляют местные поселения. Удивительным образом эти пришлые иереи представляют центры и духовной жизни, и глобализации одновременно.

Например, священник в одном из сел был родом из Москвы. С конца 1980-х гг. он уехал на ПМЖ в США, штат Орегона, где и женился (супруга из семьи часовенных). В 2003 г. его поставили на данный украинский приход. Так в украинском селе появилась семья «американцев»- он, супруга и шестеро их детей. Безусловно заботясь о сохранении чистоты веры, семья представляет собой одновременно транслятора современной модернизации в американском варианте. Бытовые и производственные стандарты вступали в явное противоречие с окружающей жизнью. Например, доводилось слышать от односельчан не только комплимент их святости, но и их компьютеру («дык, почти, как у батюшки внук компьютер купил»). Когда начались у части прихожан споры с этим батюшкой, его американское происхождение ставили ему в вину, полагая что это объясняет его роль «глобализатора» (например, заменил старые «намоленные окна» (?!) на современные стеклопакеты). Пример иного вектора, но схожий по своему значению - другой иерей, местный по происхождению, был временно привлечен к духовному окормлению старообрядческого населения Австралии («А наш батюшка к кенгуру поехал», - с гордостью говорили прихожане, подчеркивая, что их наставник пользуется востребованностью даже в Австралии).

Важным является то, что личностные социальные связи не были разрушены. В гости и по духовным делам дунайские общины посещают граждане Германии, США, Австралии и прочих адептов глобализации. Да и сами священники, участвуя в общей жизнедеятельности старообрядческой 
церкви достаточно мобильны. Все это способствует сжатию пространств, что составляет важную черту глобализирующегося мира (Бауман, 2004: 10).

Важно и то, что группа липован находится на пограничном положении между двумя духовными центрами староверия - Браилой (Румыния) и Москвой. Не вступая в сложные вопросы взаимодействия этих двух митрополий, липоване активно поддерживают межприходское трансграничное общение. Тяготение к своему религиозному миру разрушает не только политические границы, но и некие канонические договоренности.

Менее выразительная роль конфессионального центра в часовенной среде Тувы. Сознательно избегая инноваций, наставники, вроде как, в полной мере не могут считаться акторами глокализации, однако... Как биографии этих персон, так и их взаимосвязи сугубо конфессиональные делают их масштабными субъектами. Как и все часовенные, представители конфессионального центра редко родились в общине, где проживают. Лица среднего возраста на вопрос, откуда они, отвечают тремя-четырьмя топонимами. Такая мобильность характерна для группы в целом, нередко в этих перечислениях может оказаться далекое пространство: от Китая до США. История группы сложна и запутана, а отдельная судьба может быть еще сложнее коллективной. Естественно, что в таких обстоятельствах привнесение стандартов и укладов проявляется непосредственно.

В 1990-е гг. была подорвана замкнутость группы часовенных, они стали активно общаться с одноверцами не только Урала, Сибири и Дальнего Востока, но и со своими собратьями по всему миру: Южная и Северная Америка, Австралия. Такая сетевая коммуникация выступала глобализатором не только в конфессиональной сфере, но и в бытовой и социальной. Среди часовенных нередко можно встретить сейчас людей, которые родились в Китае, Австралии, Аргентине или Бразилии. Вместе с ними, на Енисей попадают элементы и комплексы внешнего мира, несмотря на весь традиционализм мышления и представлений.

Предприниматель. Экономическая мощь старообрядческих общин является хрестоматийным примером их жизнедеятельности. Не удивительно поэтому, что в условиях рыночных отношений они полностью раскрывают этот потенциал. Благодаря активной жизненной позиции, часть представителей включилась во всевозможные формы предпринимательства - торговлю, туризм, производство.

Важно, что устойчивые связи с внешним миром, неизбежные при таком укладе, ставят обычно предпринимателей в маргинальное положение в религиозной общине. Их как бы выталкивает на периферию конфессиональной практики сама ситуация. При этом, окончательного разрыва не происходит.

«Наше дело - заботиться о том, чтобы сейчас выжить, а о душе нашей - пусть церковные пекутся. Когда могу на службу схожу, стараюсь на большие праздники в храме постоять. А так - всегда на свечку через бабушек всегда передаю. Прав батюшка, но и я прав - если не заработаю, то на что все мы, включая его, жить будем», - делился со мной один успешный бизнесмен (ПМА, 2013, г. Измаил Одесской области, Украина).

Мобилизация таких людей происходит в случае серьезных событий в общине. Их привлекают для ремонта или строительства церквей, «на столы» для праздничных обедов и т. д. Конечно, канула в Лету христианская традиция «десятины», когда десятую часть дохода жаловали «на Церковь». Но в реликтовой форме она присутствует в современной практике - верующие считают необходимым выделить храму некую часть своей прибыли.

Изменения мира иногда присутствует в общине посредством предпринимателей непосредственно в развитии этнокультурного туризма. Здесь обнаруживается пакетность в совмещении современной культуре туристов с традиционной культурой староверов, становящейся своеобразным товаром. Исследователи подобных процессов отмечают, что в глобализирующемся мире формируется новая «мозаичная» культура, происходит разрушение и вестернизация национальных культур. На этом фоне во многих странах происходит «этнический бум», нашедший выражение в разных формах, в том числе и в расширении зеленого (сельского, этнокультурного) туризма. Не обошел он стороной и старообрядческие поселения Придунавья - особо Вилково и Приморское. Специфичные природные возможности вместе с экзотическим населением становятся брэндами продажи для туристов Европы и СНГ. На уровне ярких символов старообрядческая (липованская) культура становится орнаментом отдыха.

Показательно, что большинство втянутых в этот туристический бизнес, отходят от церковной практики, сохраняя лишь память и осознание «мы -липоване, староверы, предки наши из-за веры 
сюды бежали...». Выразительная локальность в сочетании с внутренними душевными переживаниями становятся всего лишь продуктом рыночной индустрии, составляя сегмент глобального туризма.

Справедливости ради стоит заметить, что часть предпринимателей стала импортировать «глобальный» товар для туристов и местных жителей. Так, например, в старообрядческом селе появились «дискотеки», «бары», «луна-парки» и т. д. И все это устроено «по мировым стандартам» шоу-индустрии. Таким экзотическим приобретением современности является и «Страусиное ранчо». Не пережило это ранчо политический кризис 2014 г. и на его месте создано успешное украинское предприятие «Брынзарня», где подается совершенно импортный продукт, приправленный местной экзотикой.

Еще один доходный вид бизнеса подчеркивает товарность местных условий для общеевропейского рынка. В то время, как местные жители устойчиво стремятся покрыть свои современные коттеджи финской или польской черепицей, их традиционный камыш оказался востребованным в Европе (Голландия, Германия и т. д.), где наблюдается мода на экологически чистые натуральные материалы. Масштаб поставок настолько значительный, что почти все население Вилково и округи втянуто в его заготовку (за «евросноп» тростника заготовители платят 2-3 гривны, а получают 1-2 евро (соотношение на 2008 г.)).

На Енисее предприниматели-староверы больше ориентированы на внутренний российский рынок. Большинство из них выполняют роль посредников между праведной жизнью мирян и внешними структурами мира. В этом случае нередко еще действует христианская этика, усиленная староверческим отношением к ответственности. Сращивание забот о «телесном и душевном спасении» выстраивается согласно логике богоугодного дела, помноженного на успешность коммерческой составляющей.

Яркий пример - конфессиональный туризм. Несмотря на условную замкнутость общин, здесь развиваются такие инфраструктурные компоненты как паломничество (нередко - из-за рубежа) и социальное призрение. Ритуальный объезд старообрядческих святынь Сибири (особенно «скитов на севере») характерен для многих верующих со всего Мира. Это создает надежную конфессиональную сеть акторов, которые объединены экономической кооперацией. Вместе с тем, нередко можно услышать рассуждения о том, кто «у нас, из родни в скитах». Вклады в монастырский быт - от натурального продукта до человеческого ресурса трудом - воспринимаются не только как религиозный долг, но и имеют явный признак социальной солидарности. В этих контекстах экономическая предприимчивость осознается как «христианское дело».

Так на встречу друг другу идет процесс сращивания глобальных стандартов и реальной локальности. Взаимный экспорт-импорт приводит к феноменальной глокализации.

Власть. Если в исторический период власть не только не пускала старообрядцев к себе, но и всячески эксплуатировала их «инаковость», то на современном этапе сами старообрядцы не проявляют стремления войти в институции не только власти, но и самоуправления. Практически по всем липованским поселениям мы сталкивались со своеобразной ситуацией - крайне редко старообрядцы занимали «посты» даже на уровне директоров школ, председателей КСП (коллективных сельхозпредприятий) или советов. Эти должности отдавались пришлым соседям - украинцам, молдаванам, болгарам и т. д. Если и попадались старообрядцы, то это оказывались представительницы женского пола.

Власти вообще воспринимаются как порождение (вернее - присвоение) «дьявола». А вот их низшие таксоны - индифферентность. Вековые традиции сопротивления сочетались с христианским смирением перед делами «кесарей». На этом дуализме построено законопослушание старообрядцев.

Если в других регионах такие важные акции правительств и администраций как переписи населения, прививки, составление фискальных списков и т. п. вызывали протесты ${ }^{1}$, то липоване остались равнодушными к таким проявлениям власти. Наоборот, активно включались в раздачу приватизационных сертификатов, распаевку земель по реформе 2001 г. и прочее.

Вертикаль власти как агент унификации выступает важным проводником глобализационных процессов. Близкие функции выполняют СМИ. Несмотря на явный сетевой, а не иерархический характер современные коммуникационные средства привносят в размеренную жизнь новшества. В

\footnotetext{
${ }^{1}$ Нам самим доводилось общаться со староверами, не получающими пенсию в связи с тем, что их «сам бес» (отдел социального страхования - СОБЕС) раздает (Черниговщина). А среди липован последние массовые протесты вызывали закрытие и разрушение церквей в годы Советской власти.
} 
обстоятельствах старообрядческой культуры, сознательно ориентированной на уважение и даже сакрализацию письменного кода, месседжи прессы интенсивно включаются в повседневность, изменяя ее.

Среди часовенных эти же моменты еще более последовательные. «Кадровые» (так называют всех, кто формально работает в любой администрации) долго вообще исключались из состава общин. Буквально на наших глазах происходила трансформация: понимая, что могут прислать чужаков, староверы начали из своей среды выдвигать представителей для бюрократических институций, школ и хозяйственной администрации. Это гарантировало им условное самоуправление и противостояние внешнему влиянию. Так, например, в одном из поселков на протяжении ряда лет не запускали компьютерный класс, ссылаясь на публичное нежелание общины. Эту функцию последовательно смогла отстаивать носительница староверческого мировоззрения, но включенная в систему образования. Или, в другом случае, светская власть в одном лице соединилась с церковным старостой, который в обеих случаях «правил» согласно своему представлению об эффективности.

Гендерные аспекты. Очевиден факт доминирования в глобализационных проявлениях детскоподросткового поколения над старшим. Ориентированные на завтрашний день самой природой своего социализируемого положения, молодежь осваивает инновации быстрей своих старших товарищей. И дело не только в отягощенности предыдущего опыта, но и в самой глобальной культуре, которая своим субъектом видит именно их. Яркий пример - День Святого Валентина (14 февраля), который ученики средних школ назвали в ряду своих праздников наряду с Рождеством, Пасхой и т. д. В то же время кроме учителей этот праздник не известен среди их односельчан. Современная массовая культура в ее потребительском аспекте рассчитана на молодые поколения.

Показателен также пример в одном из радикальных поселков часовенных. Несмотря на публичный запрет Интернета и смартфона, возле сельсовета существует «вай-фай зона». На ней, в темное время суток мы наблюдали несколько десятков подростков, которые с помощью современных девайсов активно пользовалась социальными сетями.

Вместе с тем глокализация трансформировала семантическую нагрузку полов. Если в домодерном обществе староверов женщины играли роль сохранения дома и семьи, а мужчина - ритуальнорепрезентативные и инновационного развития культуры (Пригарин, 2003: 61; Прігарін, 2003), то теперь акценты принципиально сместились. Женщины активно включились не только в общественноэкономическую жизнь (выше мы указывали примеры вхождения их во власть), но и начали занимать ведущие места в храме. Они все чаще выполняют обязанности церковных старост, казначеев и т. д. Еще в 1970-е гг. их не допускали исполнять богослужения перед алтарем (на крылосе) (Смилянская, Денисов, 2007: 96), то теперь среди «крылошан» редко встретишь мужчин.

Часовенные пока избегают подобных трансформаций. Среди них еще сохраняется гармоничный гендерный баланс как в конфессиональной, так и в хозяйственно-бытовой жизни. Хотя нельзя не отметить заметно выросшую роль женского пола. Например, увеличение и количественное черноризец, и их участия в религиозной жизни: переписывание книг, создание новых текстов и смыслов, разрешении конфессиональных вопросов жизнедеятельности и т. д.

Новые времена изменили традиционное разделение полов и их функциональные нагрузки существенно изменились. На фоне этого женский пол занял ведущие позиции не только в физическом выживании, но и в заботах о душе. Пока плохо понятно - последствия ли или предпосылка глокализации? Скорее всего, просто ее проявления и движущая сила.

\section{Заключение}

Таким образом, краткое рассмотрение глокализации в старообрядческой среде украинского и тувинского пограничья позволяет нам выделить несколько общих тенденций. Их проявления подчеркиваются консервативностью и сознательной традиционностью рассматриваемого сообщества. Это позволяет не только проследить специфичность этого процесса в этноконфессиональном плане, но и считать их эвристически ценными и адекватными для других этнокультурных групп.

Из наблюдений следует, что глобализация воспринимается не как простой механический импорт из некого центра, а скорее - имманентный этап саморазвития. Весь инновационный опыт расценивается как естественное эволюционное продолжение истории. В обстоятельствах староверческой среды категориальные рамки процесса вполне вписываются в эсхатологическую концепцию. Своя глобальность в виде Конца Света проецируется на современные изменения. 
Наступление новых стандартов и условий жизни не только унифицирует мир, сколько порождает «праздник разнообразия», раскрепощает инаковость и эмансипирует несхожесть. Наличие некой центральной нормы окончательно завершает процессы отчуждения личности и группы от нее. За счет несоответствия своего «закона» с общемировым порядком свои парадигмы легализуются и дают право на самобытность.

Глобальные ценности идут в местные масштабы, где получают свое право на бытование лишь в случаях соответствия их локальному измерению. Такая диалектика вполне полисемантична и соответствует старообрядческому мировоззрению. Разностадиальность их культурных кодов вписывается в требование сочетания различных укладов жизни (пакетов) современности. При этом порождается надежда на собственную включенность в общемировое пространство - расчет на будущее своей религиозной системы в ряду прочих мировоззренческих представлений.

\section{СПИСОК ЛИТЕРАТУРЫ}

Анастасова, Е. Е. (1998) Старообредците в България: мит - история - идентичност. София : Проф. Марин Дринов. 127 с. (На болг. яз.)

Анастасова, Е. Е. (2006) Старообрядцы в Румынии и Болгарии в период перехода // Культура русских-липован в национальном и международном контексте : сборник научных сообщений, представленных на IV международном симпозиуме ОРЛР. Вып. 4. / отв. ред.: И. Евсеев, С. Молдован, Т. Воронцова. Бухарест : CRLR. 464 с. C. 24-38.

Астафьева, Е. Н., Кошелева, О. Е., Мещеркина, Е. Ю., Нуркова, В. В. (2001) Биографическое интервью. Труды кафедры педагогики, истории образования и педагогической антропологии. Вып. 12 / под ред. В. Г. Безрогова. М. : Изд-во УРАО. 86 с.

Бауман, 3. (2004) Глобализация: последствия для человека и общества : пер. с англ. М. Л. Коробочкина. М. : Весь мир. 188 с.

Биографический метод в социологии: история, методология и практика (1994) : сборник статей / редкол. : Е. Ю. Мещеркина, В. В. Семенова. М. : Ин-т социол. 147 с.

Бергер, П. Л. (2004) Введение. Культурная динамика глобализации // Многоликая глобализация / под ред. П. Бергера и С. Хантингтона. М. : Аспект Пресс. 379 с. С. 7-24.

Бондаренко, Г. Б. (2005) Трансформація звичаєво-обрядової культури та морально-ціннісних орієнтацій сільського населення України в умовах глобалізації (с.Червона Слобода, Черкаська область) // Українська культура в контексті світових глобалізаційних процесів / відп. ред. Г. А. Скрипник. Київ : ІМФЕ ім. М. Т.Рильського НАН України. 360 с. С. 27-38 (На укр. яз.).

Быкова, Е. В., Костров, А. В. (2018а) «Широкий путь» в сознании старообрядцев Енисея: современная народная картинка о процессах глобализации // Традиционная культура. Т. 20. № 2. С. 62-76.

Быкова, Е. В., Костров, А. В. (2018b) «Игра пространства» в современном старообрядческом лубке // Научные труды. Проблемы развития отечественного искусства. Вып. 44. Январь - март 2018. Проблемы развития отечественного искусства / науч. ред. В. А. Леняшин. СПб. : б. и. 235 с. С. 174-185.

Быкова, Е. В., Пригарин, А. А., Стороженко, А. А. (2018) «Светильник XX столетия, наставник и учитель слову Божию»: памяти Мурачева Афанасия Герасимовича (24 октября 1921 - 12 сентября 2008) // IV Центральноазиатские исторические чтения. Пространство культур: через призму единства и многообразия : сб. материалов Международной научно-практической конференции / под ред. З. Ю. Доржу, В. М. Дамдынчап, Ю. В. Попкова, А. А. Стороженко. Кызыл : Изд-во ТувГУ. 350 с. С. 146-151.

Быкова, Е. В., Пригарин, А. А. (2019) Мир визуальных образов старообрядцев Тувы: от иконы и лубочной картинки до фотографии // Новые исследования Тувы. № 1. С. 75-94. DOI: https://doi.org/10.25178/nit.2019.1.6

Верменич, Я. (2003) Теоретико-методологічні проблеми історичної регіоналістики в Україні / наук. ред. П. Т. Тронько. Киев : Інститут історії України НАН України. 516 с. (На укр. яз.).

Верменич, Я. (2006) Парадигими «оновлення» в історичної науці: новий регіоналізм // Ей-дос. Вип. 2. С. $202-205$. (На укр. яз.).

Генчев, С. (1989) Теренното етнографско изследване [Полевое этнографическое исследование]. Велико Търново : ВТУ. 286 с. (На болг. яз.).

Громов, Г. Г. (1966) Методика полевых этнографических исследований. М. : МГУ. 108 с.

Данилко, Е. С. (2002) Старообрядчество на Южном Урале: очерки истории и традиционной культуры. Уфа : Гилем. 218 с.

Зольникова, Н. Д. (2018) Сочинение писателя-старовера А. Г. Мурачева «О начертании» в свете споров о штрихкоде как печати антихриста // Гуманитарные науки в Сибири. Т. 25. № 1. С. 96-100. DOI: https://doi.org/10.15372/ HSS20180115 
Керов, В. В. (2016) “Се человек и дело его...”: конфессионально-этические факторы старообрядческого предпринимательства. М. : Изд-во «Экон-Информ». 590 с.

Любимова, Г. В. (2017) Модернизация земледельческого труда в культуре сибирских старообрядцев // Уральский исторический вестник. № 2(55). С. 122-130.

Поздеева, И. В. (2006) Материальное и духовное в жизни старообрядческих общин // Культура русских-липован в национальном и международном контексте : сборник научных сообщений, представленных на IV международном симпозиуме ОРЛР. Вып. 4 / отв. ред. Е. Евсеев, С. Молдован, T. Воронцова. Бухарест : CRLR. 464 c. C. $256-268$.

Покровский, Н. Н., Зольникова, Н. Д. (2002) Староверы-часовенные на востоке России в XVIII-XX вв. : Проблемы творчества и общественного сознания. М. : Памятники исторической мысли. 471 с.

Полевая кухня: как провести исследование (2004) / под. ред. Н. Гончаровой. Ульяновск : Симбирская книга. $180 \mathrm{c}$.

Пригарин, А. А. (2003) Мужские стереотипы поведения в старообрядческой среде: на материалах русскихлипован Подунавья // «Мужское» в традиционном и современном обществе. Материалы научной конференции / редакторы: Д. В. Громов, И. А. Морозов. М. : Институт этнологии и антропологии им. Н. Н. Миклухо-Маклая РАН. 98 с. С. $60-63$.

Прігарін, О. А. (2003) Борода та її знакові функції в уявленнях старообрядців Подунав’я // Тіло в текстах культур. Київ. Матеріали конференції / голов. ред. Г. Скрипник, упоряд.: О. Боряк, М. Маєрчик. Київ : б. в. 222 с. С. $63-68$. (На укр. яз.).

Пригарин, А. А. (2004) Предпосылки этноконфессиональной выразительности культуры русских-старообрядцев (липован) Юго-Восточной Европы // Ethnic culture : traditions a. innovations / Vitautas Magnus univ / Ed.-in-chief Romualdas Apanavičius. Kaunas : Vytautas Magnus univ. press. 439 p. P. 356-366.

Расков, Д. Е. (2007) Судьба старообрядчества в эпоху Постмодерна // Судьба старообрядчества в XX - начале XXI вв.: история и современность. Зб. наук. праць та матеріалів / отв. ред. и сост. С. В. Таранец. Київ ; Куреневка ; Чечельник : б. и. 235 с. С. 52-62.

Романов, Е. Р. (1901) Из старообрядческой литературы // Могилевская старина: сборник статей «Могилевских губернских ведомостей» / под ред. Е. Р. Романова. Вып. ІІ. Могилев: Типография губернского правления. 160 с. С. 79-86.

Рыговский, Д. С. (2018a) «Правило чашки»: гостеприимство старообрядцев в антропологической перспективе // IV Центральноазиатские исторические чтения. Пространство культур: через призму единства и многообразия: сборник материалов Международной научно-практической конференции / под ред. З. Ю. Доржу, В. М. Дамдынчап, Ю. В. Попкова, А. А. Стороженко. Кызыл : Изд-во ТувГУ. 350 с. С. 172-177.

Рыговский, Д. С. (2018b) «Чистое», «мирское» и «поганое»: старообрядческая концептуализация ритуальной чистоты // Культура славян и культура евреев: диалог, сходства, различия. № 1. С. 167-186. https://doi. org/10.31168/2658-3356.2018.12

Рыговский, Д. С. (2019а) Влияние религиозных практик на социальную структуру енисейских староверов // Антропологический форум. № 41. C. 11-35. DOI: https://doi.org/10.31250/1815-8870-2019-15-41-11-35

Рыговский, Д. С. (2019b) Механизмы различения в среде сибирских староверов // Язык, книга и традиционная культура позднего Русского средневековья в науке, музейной и библиотечной работе: труды IV Международной научной конференции. Сборник научных статей / составители: Ю. С. Белянкин, Е. В. Воронцова, Н. В. Литвина. Вып. 10. Мир старообрядчества. Выпуск XXX. Серия II: Труды исторического факультета МГУ. М. : Изд-во Московского университета. 783 с. С. $728-737$.

Рыговский, Д. С. (2019c) Техника и ее репрезентация как источник религиозного опыта в енисейском старообрядчестве // Государство, религия, церковь в России и за рубежом. № 4 (37). C. 19-44. DOI: https://doi. org/10.22394/2073-7203-2019-37-4-19-44

Смилянская, Е. Б., Денисов, Н. Г. (2007) Старообрядчество Бессарабии: книжность, певческая культура. М. : Индрик. 477 с.

Сморгунова, Е. М. (1996) Современная жизнь в ожидании конца света (некоторые эсхатологические представления пермских староверов в последние годы XX века)//Старообрядчество: история, культура, современность : сборник тезисов / ред.: О. П. Ершова, В. И. Осипов, Е. И. Соколова. М. : Музей истории и культуры старообрядчества. 176 c. С. $22-25$.

Соболева, Л. С. (1997) Американское сочинение об Антихристе-компьютере в интерпретации уральского старовера // Исследования по истории книжной и традиционной народной культуры Севера : межвуз. сб. науч. тр. / отв. ред. Т. Ф. Волкова. Сыктывкар : СГУ. 235 с. С. 118-130.

Стороженко, А. А. (2018) Конфессиональные миграции старообрядцев «енисейского меридиана» во второй половине XIX - начале XX в.// Миграционные процессы в Сибири: народы, культуры, государственная политика : 
сборник научных трудов Международной научно-практической конференции / под ред. М. А. Жигуновой, И. И. Кротта. Омск : Издательский центр КАН. 327 с. С. 44-49.

Стороженко, А. А. (2019а) Старообрядческие монастыри «енисейского меридиана» в XX веке: истоки, традиции и современное состояние // Новые исследования Тувы. № 1. С. 4-15. DOI: https://doi.org/10.25178/nit.2019.1.1

Стороженко, А. А. (2019b) История старообрядческой белокриницкой общины в Туве во второй половине XIX - начале XX в. // Современные этнические процессы на территории Центральной Азии: проблемы и перспективы: сборник материалов второй Международной научно-практической конференции / ред. коллегия: 3. Ю. Доржу, В. М. Дамдынчап. Кызыл : Изд-во ТувГУ. 222 с. С. 165-169.

Стороженко, А. А., Татаринцева, М. П. (2019) «Прекрасная пустыня, прими меня в свою частыню». Старообрядческие скиты в верховье Енисея // Традиционная культура. Т. 20. № 2. С. 88-97. DOI: https://doi.org/10.26158/ TК.2019.20.2.007

Татаринцева, М. П. (2006) Старообрядцы в Туве: историко-этнографический очерк. Новосибирск : Наука. 216 с.

Татаринцева, М. П. (2018) Проблема сохранения культурных традиций в изменяющихся условиях (на примере старообрядцев в Туве) // IV Центральноазиатские исторические чтения. Пространство культур: через призму единства и многообразия: сборник материалов Международной научно-практической конференции / под ред. 3. Ю. Доржу, В. М. Дамдынчап, Ю. В. Попкова, А. А. Стороженко. Кызыл : Изд-во ТувГУ. 350 с. С. 177-181.

Татаринцева, М. П., Стороженко А. А. (2015) Старообрядцы Тувы: ретроспектива и современность. Saarbrücken : LAP LAMBERT Academic Publishing. 137 c.

Трушкова, И. Ю. (2002) Старообрядчество как позднесредневековое православие (этнокультурологический аспект)//Старообрядчество: история, культура, современность : материалы VI научно-практической конференции / ред.-сост.: В. И. Осипов и др. М. : Музей истории и культуры старообрядчества. 542 с. С. 441-451.

Atkinson, P. (2000) Metody badań terenowych. Poznań : Zysk i s-ka. 329 p.

Chiseri-Strater, E., Stone, S., B. (1997) Fieldworking: Reading and Writing Research Upper Saddle River. New York : Prentice Hall. 369 p.

Denzin, N. K. (1989) Interpretative Biography. Newberry Park, SA: Sage. 95 p.

Hamersley, M., Atkinson, P. (2000) Metody badań terenowych. Poznań : Zysk i S wydawnictwo. 328 p.

Handbook of Methods in Cultural Anthropology (2000) / Ed. H. R. Bernard. London : Walnut Creek. 816 p.

Kopczyńska-Jaworska, B. (1971) Metodyka etnograficznych badań terenowych. Łódź : Hammersley. 326 p.

Prygarin, O. A. (2004) Les “vieux-croyants” (Lipovane) du delta du Danube // Ethnologie Française. T. XXXIV. UkraineУкраїна: terrains, ėveils. № 2 (32). 373 p. P. 259-266.

Russel, B. H. (1995) Research Methods in Anthropology. Qualitative and Quantitative Approaches. Lanham, Md. : Altamira Press, Walnut Creek. 666 p.

Spradley, J. P. (1979) The Ethnographic Interwiew. New York : Holt, Rinehart and Winston. 247 p.

Spradley, J. P. (1980) Participant Observation. New York : Holt, Rinehart and Winston. 283 p.

Дата поступления: 06.05.2021 г.

\section{REFERENCES}

Anastasova, E. E. (1998) Staroobredtsite v Bzlgariia: mit - istoriia - identichnost [Old Believers in Bulgaria: myth, history, udentity]. Sofia, Prof. Marin Drinov. 127 p. (In Bolg.)

Anastasova, E. E. (2006) Staroobriadtsy v Rumynii i Bolgarii v period perekhoda [Old Believers in Romania and Bulgaria during the transition period]. In: Kul'tura russkikh-lipovan $v$ natsional'nom i mezhdunarodnom kontekste [Culture of Lipovan Russians in the national and international context] : a collection of research papers presented at the $4^{\text {th }}$ International Symposium of the ORLR. Issue 4 / ed. by I. Evseev, S. Moldovan and T. Vorontsova. Bukharest, CRLR. 464 p. Pp. 24-38. (In Russ.).

Astaf'eva, E. N., Kosheleva, O. E., Meshcherkina, E. Yu. and Nurkova, V. V. (2001) Biograficheskoe interv'iu. Trudy kafedry pedagogiki, istorii obrazovaniia i pedagogicheskoi antropologii [The biographical interview. Proceedings of the Department of Pedagogy, History of Education and Pedagogical Anthropology]. Issue 12 / ed. by V. G. Bezrogov. Moscow, URAO Publ. 86 p. (In Russ.).

Bauman, Z. (2004) Globalizatsiia: posledstviia dlia cheloveka i obshchestva [Globalization. The human consequences]: transl. from Engl. by M. L. Korobochkin. Moscow, Ves’ mir. 188 p. (In Russ.).

Biograficheskii metod v sotsiologii: istoriia, metodologiia i praktika [Biographical method in sociology: history, methodology and practice] (1994): a collection of research articles / editorial board: E. Yu. Meshcherkina and V. V. Semenova. Moscow, Institute of Sociology. 147 p. (In Russ.). 
Berger, P. L. (2004) Vvedenie. Kul'turnaia dinamika globalizatsii [Introduction. Cultural dynamics of globalization]. In: Mnogolikaia globalizatsiia [Many Globalizations. Cultural Diversity in the Contemporary World] / ed. by P. Berger and S. Huntington, transl. from Engl. Moscow, Aspekt Press. 379 p. Pp. 7-24. (In Russ.).

Bondarenko, G. B. (2005) Transformatsiia zvichaєvo-obriadovoï kul'turi ta moral'no-tsinnisnikh orientatsii sil's'kogo naselennia Ukraïni v umovakh globalizatsiï (s.Chervona Sloboda, Cherkas'ka oblast') [Transformation of the culture of customs and rituals, and morals and value orientations of the rural population of Ukraine under globalization: the case of Chervona Sloboda village, Cherkasy oblast)]. In: Ukraïns'ka kul'tura v konteksti svitovikh globalizatsiinikh protsesiv [Ukrainian culture in the context of the globalization processes around the world] / ed. by G. A. Skripnik. Kiev, IMFE im. M. T. Ril's'kogo NAN Ukraïni. 360 p. Pp. 27-38 (In Ukr.)

Bykova, E. V. and Kostrov, A. V. (2018a) «Shirokii put’» v soznanii staroobriadtsev Eniseia: sovremennaia narodnaia kartinka o protsessakh globalizatsii ["A wide path" in the consciousness of the Old Believers of the Yenisei: modern folk view of the processes of globalization]. Traditsionnaia kul'tura, vol. 20, no. 2, pp. 62-76. (In Russ.).

Bykova, E. V. and Kostrov, A. V. (2018b) «Igra prostranstva» v sovremennom staroobriadcheskom lubke ["The game of space" in the contemporary Old Belief lubok]. In: Nauchnye trudy. Problemy razvitiia otechestvennogo iskusstva [Research works. Problems of the development of Russian art]. Issue 44. January - March 2018 / ed. by V. A. Leniashin. St. Petersburg, s. n. 235 p. Pp. 174-185.

Bykova, E. V., Prigarin, A. A. and Storozhenko, A. A. (2018) «Svetil'nik XX stoletiia, nastavnik i uchitel' slovu Bozhiiu»: pamiati Muracheva Afanasiia Gerasimovicha (24 oktiabria 1921 - 12 sentiabria 2008) ["A lamp of the twentieth century, a mentor and teacher of the word of God": in the memory of Afanasy Gerasimovich Murachev (October 24, 1921 - September 12, 2008)]. In: IV Tsentral'noaziatskie istoricheskie chteniia. Prostranstvo kul'tur: cherez prizmu edinstva i mnogoobraziia [4th readings in Central Asian history: The space of cultures through the prism of unity and diversity]. Proceedings of an international conference / ed. by Z. Yu. Dorzhu, V. M. Damdynchap, Yu. V. Popkova and A. A. Storozhenko. Kyzyl, TuvSU Publ. 350 p. Pp. 146-151. (In Russ.).

Bykova, E. V. and Prigarin, A. A. (2019) Mir vizual'nykh obrazov staroobriadtsev Tuvy: ot ikony i lubochnoi kartinki do fotografii [The world of visual images of the Tuva Old Believers: from icons and popular prints to photos]. New Research of Tuva, no. 1, pp. 75-94. (In Russ.). DOI: https://doi.org/10.25178/nit.2019.1.6

Vermenich, Ya. (2003) Teoretiko-metodologichni problemi istorichnoï regionalistiki v Ukraïni [Theoretical and methodological problems of historical regionalism in Ukraine]. Ed. by P. T. Tron'ko. Kiev, Institut istoriï Ukraïni NAN Ukraïni. 516 p. (In Ukr.).

Vermenich, Ia. (2006) Paradigimi «onovlennia» v istorichnoï nautsi: novii regionalizm [Paradigms of "renewal" in historical studies: a new regionalism]. Ei-dos, vol. 2, pp. 202-205. (In Ukr.).

Genchev, S. (1989) Terennoto etnografsko izsledvane [Field ethnographic research]. Veliko Tъrnovo, VTU. 286 p. (In Bolg.).

Gromov, G. G. (1966) Metodika polevykh etnograficheskikh issledovanii [Methods of field ethnographic research]. Moscow, MGU. 108 p. (In Russ.).

Danilko, E. S. (2002) Staroobriadchestvo na Iuzhnom Urale: ocherki istorii i traditsionnoi kul'tury [Old Believers in the Southern Urals: Essays on History and Traditional Culture]. Ufa, Gilem. 218 p. (In Russ.).

Zol'nikova, N. D. (2018) Sochinenie pisatelia-starovera A. G. Muracheva «O nachertanii» v svete sporov o shtrikh-kode kak pechati antikhrista [The essay "On inscribing” by an Old Believer writer A. G. Murachev in the light of debates on the bar code as the Antichrist's seal]. Gumanitarnye nauki v Sibiri, vol. 25, no 1, pp. 96-100. (In Russ.). DOI: https://doi. org/10.15372/HSS20180115

Kerov, V. V. (2016) “Se chelovek i delo ego...”: konfessional'no-eticheskie faktory staroobriadcheskogo predprinimatel'stva ["Behold a man and his work...": confessional and ethical factors of Old Believers 'entrepreneurship]. Moscow, Ekon-Inform. 590 p. (In Russ.).

Liubimova, G. V. (2017) Modernizatsiia zemledel'cheskogo truda v kul'ture sibirskikh staroobriadtsev [Modernization of agricultural labour in the culture of Siberian Old Believers]. Ural Historical Journal, no. 2(55), pp. 122-130. (In Russ.).

Pozdeeva, I. V. (2006) Material'noe i dukhovnoe v zhizni staroobriadcheskikh obshchin [The material and spiritual in the life of Old Believers' communities]. In: Kul'tura russkikh-lipovan v natsional'nom i mezhdunarodnom kontekste [The culture of Lipovan Russians in the national and international context] : a collection of papers presented at the IV International Symposium of the ORLR. Issue 4 / ed. by E. Evseev, S. Moldovan and T. Vorontsova. Bukharest, CRLR. 464 p. Pp. $256-268$. (In Russ.).

Pokrovsky, N. N. and Zol'nikova, N. D. (2002) Starovery-chasovennye na vostoke Rossii v XVIII-XX vv. : Problemy tvorchestva i obshchestvennogo soznaniia [Old believers of the Chasovennoye accord in the East of Russia in the 18th - 20th centuries: Problems of creativity and public consciousness]. Moscow, Pamiatniki istoricheskoi mysli. 471 p. (In Russ.).

Polevaia kukhnia: kak provesti issledovanie [Field kitchen: how to conduct a study] (2004) / ed. by N. Goncharova. Ul'ianovsk, Simbirskaia kniga. 180 p. (In Russ.). 
Prigarin, A. A. (2003) Muzhskie stereotipy povedeniia v staroobriadcheskoi srede: na materialakh russkikh-lipovan Podunav'ia [Stereotypes of male behavior among Old Believers: the case of Lipovan Russians along the Danube]. In: «Muzhskoe» v traditsionnom i sovremennom obshchestve. Materialy nauchnoi konferentsii [The "Masculine" in traditional and modern society: Proceedings of a research conference] / ed. by D. V. Gromov and I. A. Morozov. Moscow, N. N. MiklouhoMaclay Institute of ethnology and anthropology RAS. 98 p. Pp. 60-63. (In Russ.).

Prigarin, O. A. (2003) Boroda ta ïï znakovi funktsiï v uiavlenniakh staroobriadtsiv Podunav’ia [The beard and its iconic functions in the views of the Old Believers of the Danube Region]. In: Tilo v tekstakh kul'tur [Body in cultural texts]. Kiev. Proceedings of a conference. / ed. by G. Skripnik. Kiev, s. n. 222 p. Pp. 63-68. (In Ukr.).

Prigarin, A. A. (2004) Predposylki etnokonfessional'noi vyrazitel'nosti kul'tury russkikh-staroobriadtsev (lipovan) Iugo-Vostochnoi Evropy [Prerequisites for the ethno-confessional expressiveness of the culture of Russian Old Believers (Lipovans) in South-Eastern Europe]. In: Ethnic culture : traditions a. innovations / Vytautas Magnus univ / Ed.-in-chief Romualdas Apanavičius. Kaunas, Vytautas Magnus Univ. Press. 439 p. Pp. 356-366. (In Russ.).

Raskov, D. E. (2007) Sud'ba staroobriadchestva v epokhu Postmoderna [The fate of the Old Believers in the Postmodern era]. In: Sud'ba staroobriadchestva $v X X-$ nachale XXI vv.: istoriia $i$ sovremennost' [The fate of the Old Believers in the $X X$ - early XXI centuries: history and modernity] / ed. and comp. by S. V. Taranets. Iev, Kurenevka; Chechel'nik, s. n. 235 p. Pp. 52-62. (In Russ.).

Romanov, E. R. (1901) Iz staroobriadcheskoi literatury [From Old Believer literature]. In: Mogilevskaia starina [The antiquity of Mogilev]: a collection of articles of the Mogilev Provincial Gazette / ed. by E. R. Romanov. Vol. II. Mogilev, Tipografiia gubernskogo pravleniia. 160 p. Pp. 79-86. (In Russ.).

Rygovskii, D. S. (2018a) «Pravilo chashki». Gostepriimstvo staroobriadtsev v antropologicheskoi perspektive [“The rule of the cup". The hospitality of the Old Believers in an anthropological perspective]. In: IV Tsentral'noaziatskie istoricheskie chteniia. Prostranstvo kul'tur: cherez prizmu edinstva i mnogoobraziia [4th readings in Central Asian history: The space of cultures through the prism of unity and diversity]. Proceedings of an international conference / ed. by Z. Yu. Dorzhu, V. M. Damdynchap, Yu. V. Popkova and A. A. Storozhenko. Kyzyl, TuvSU Publ. 350 p. Pp. 172-177. (In Russ.).

Rygovskii, D. S. (2018b) «Chistoe», «mirskoe» i «poganoe»: staroobriadcheskaia kontseptualizatsiia ritual'noi chistoty [The 'pure', 'profane' and 'filthy': Old Believers' Conceptualization of Ritual Purity]. Kul'tura slavian i kul'tura evreev: dialog, skhodstva, razlichiia, no. 1, pp. 167-186. (In Russ.). https://doi.org/10.31168/2658-3356.2018.12

Rygovskii, D. S. (2019a) Vliianie religioznykh praktik na sotsial'nuiu strukturu eniseiskikh staroverov [The influence of religious practices on the Social Structure of Yenisei Old Believers]. Antropologicheskij forum, no. 41, pp. 11-35. (In Russ.).

Rygovskii, D. S. (2019b) Mekhanizmy razlicheniia v srede sibirskikh staroverov [Mechanisms of differentiation among Siberian Old Believers]. In: Iazyk, kniga i traditsionnaia kul'tura pozdnego Russkogo srednevekov'ia $v$ nauke, muzeinoi $i$ bibliotechnoi rabote [Language, book and traditional culture of the Late Russian Middle Ages in research, museum and library work]: proceedings of $4^{\text {th }}$ International Research Conference. A collection of research articles / comp. by Yu. S. Beliankin, E. V. Vorontsova and N. V. Litvina. Vol. 10. Mir staroobriadchestva. Vypusk XXX. Seriia II: Trudy istoricheskogo fakul'teta MGU. Moscow, Izd-vo Moskovskogo universiteta. 783 p. Pp. 728-737. (In Russ.).

Rygovskii, D. S. (2019c) Tekhnika i ee reprezentatsiia kak istochnik religioznogo opyta v eniseiskom staroobriadchestve [Technology and its representation as a source of religious experience for Old Believers of the Yenisei]. Gosudarstvo, religiia, tserkov'v Rossii i za rubezhom, no. 4 (37), pp. 19-44. (In Russ.). DOI: https://doi.org/10.22394/2073-7203-2019-37-4-19-44

Smilianskaia, E. B. and Denisov, N. G. (2007) Staroobriadchestvo Bessarabii: knizhnost', pevcheskaia kul'tura [The Old Believers of Bessarabia: book culture and song culture]. Moscow, Indrik. 477 p. (In Russ.).

Smorgunova, E. M. (1996) Sovremennaia zhizn’ v ozhidanii kontsa sveta (nekotorye eskhatologicheskie predstavleniia permskikh staroverov v poslednie gody XX veka) [Modern life in anticipation of the end of the world (some eschatological ideas of Permian Old Believers in the last years of the twentieth century)]. In: Staroobriadchestvo: istoriia, kul'tura, sovremennost' : sbornik tezisov [Old Believers: history, culture, modernity]: a collection of articles / ed.: O. P. Ershova, V. I. Osipov and E. I. Sokolova. Moscow, Muzei istorii i kul'tury staroobriadchestva. 176 p. Pp. 22-25. (In Russ.).

Soboleva, L. S. (1997) Amerikanskoe sochinenie ob Antikhriste-komp'iutere v interpretatsii ural'skogo starovera [The American essay on the computer as Antichrist as interpreted by an Old Believer from the Urals]. In: Issledovaniia po istorii knizhnoi i traditsionnoi narodnoi kul'tury Severa [Studies on the history of book and traditional folk culture of the North]: interuniversity collection of articles / ed. by T. F. Volkova. Syktyvkar, SGU. 235 p. Pp. 118-130. (In Russ.).

Storozhenko, A. A. (2018) Konfessional'nye migratsii staroobriadtsev «eniseiskogo meridiana» vo vtoroi polovine XIX - nachale XX v. [Confessional migrations of the Old Believers of the "Yenisei meridian" from the second half of the $19^{\text {th }}$ to early $20^{\text {th }}$ century]. In: Migratsionnye protsessy $v$ Sibiri: narody, kul'tury, gosudarstvennaia politika [Migration processes in Siberia: peoples, cultures, state policy]: proceedings of the international research conference / ed. by M. A. Zhigunova and I. I. Krott. Omsk, Izdatel'skii tsentr KAN. 327 p. Pp. 44-49. (In Russ.).

Storozhenko, A. A. (2019a) Staroobriadcheskie monastyri «eniseiskogo meridiana» v XX veke: istoki, traditsii i sovremennoe sostoianie [Old Belief monasteries of the «Yenisei meridian» in the 20th century: origins, traditions and current state]. New Research of Tuva, no. 1, pp. 4-15. (In Russ.). DOI: https://doi.org/10.25178/nit.2019.1.1 
Storozhenko, A.A. (2019b) Istoriia staroobriadcheskoi belokrinitskoi obshchiny v Tuve vo vtoroi polovine XIX - nachale XX v. [The history of the Old Believer Belokrinitsa community in Tuva in the second half of the XIX - early XX century.]. In: Sovremennye etnicheskie protsessy na territorii Tsentral'noi Azii: problemy i perspektivy [Modern ethnic processes in Central Asia: problems and prospects]: proceedings of the $2^{\text {nd }}$ international research conference / editorial board Z. Yu. Dorzhu and V. M. Damdynchap. Kyzyl, TuvSU Publ. 222 p. Pp. 165-169. (In Russ.).

Storozhenko, A. A. and Tatarintseva, M. P. (2019) «Prekrasnaia pustynia, primi menia V svoiu chastyniu». Staroobriadcheskie skity v verkhov'e Eniseia [“Oh, delightful skete, accept me and protect me from worldly life!”: Old Beliver sketes on the upper Yenisei]. Traditsionnaia kul'tura, vol. 20, no. 2, pp. 88-97. (In Russ.). DOI: https://doi. org/10.26158/TK.2019.20.2.007

Tatarintseva, M. P. (2006) Staroobriadtsy v Tuve: istoriko-etnograficheskii ocherk [Old believers in Tuva: a historical and ethnographic essay]. Novosibirsk, Nauka. 216 p. (In Russ.).

Tatarintseva, M. P. (2018) Problema sokhraneniia kul'turnykh traditsii v izmeniaiushchikhsia usloviiakh (na primere staroobriadtsev v Tuve) [The problem of preserving cultural traditions in changing conditions: the case of Old Believers in Tuva)]. In: IV Tsentral'noaziatskie istoricheskie chteniia. Prostranstvo kul'tur: cherez prizmu edinstva $i$ raznoobraziia [4th readings in Central Asian history: The space of cultures through the prism of unity and diversity]. Proceedings of an international conference / ed. by Z. Yu. Dorzhu, V. M. Damdynchap, Yu. V. Popkova and A. A. Storozhenko. Kyzyl, TuvSU Publ. 350 p. Pp. 177-181. (In Russ.).

Trushkova, I. Iu. (2002) Staroobriadchestvo kak pozdnesrednevekovoe pravoslavie (etnokul'turologicheskii aspekt) [Old Belief as Late Medieval Russian Orthodoxy: ethno-cultural aspect]. In: Staroobriadchestvo: istoriia, kul'tura, sovremennost' [Old Belief: History, culture, modernity]: proceedings of the $6^{\text {th }}$ research conference / ed. and comp. by V. I. Osipov et al. Moscow, Muzei istorii i kul'tury staroobriadchestva. 542 p. Pp. 441-451. (In Russ.).

Tatarintseva, M. P. and Storozhenko, A. A. (2015) Staroobriadtsy Tuvy: retrospektiva i sovremennost' [The Old Believers of Tuva: the past and present]. Saarbrucken: Lambert Academic Publishing. 137 p. (In Russ.).

Atkinson, P. (2000) Metody badań terenowych. Poznań : Zysk i s-ka. 329 p. (In Polish)

Bernard, H. R. (1995) Research Methods in Anthropology. Qualitative and Quantitative Approaches. Lanham, Md., Altamira Press, Walnut Creek. 666 p.

Chiseri-Strater, E. and Stone, S., B. (1997) Fieldworking: Reading and Writing Research Upper Saddle River. New York, Prentice Hall. 369 p.

Denzin, N. K. (1989) Interpretative Biography. Newberry Park, SA, Sage. 95 p.

Handbook of Methods in Cultural Anthropology (2000) / Ed. by H. R. Bernard. London, Walnut Creek. 816 p.

Kopczyńska-Jaworska, B. (1971) Metodyka etnograficznych badań terenowych. Łódź : Hammersley. 326 p. (In Polish).

Prygarin, O. A. (2004) Les “vieux-croyants” (Lipovane) du delta du Danube. Ethnologie Française, vol. XXXIV. UkraineUkraïna: terrains, èveils, no. 2 (32). 373 p. Pp. 259-266. (In Fr.)

Spradley, J. P. (1979) The Ethnographic Interwiew. New York, Holt, Rinehart and Winston. 247 p.

Spradley, J. P. (1980) Participant Observation. New York, Holt, Rinehart and Winston. 283 p.

Submission date: 06.05.2021. 